\title{
Self-awareness emotional learning during mediation procedures in the school context
}

\section{Sara Ibarrola-García ${ }^{1}$, Concha Iriarte ${ }^{2}$, Maite Aznárez- Sanado $^{3}$}

${ }^{123}$ Facultad de Educación y Psicología, Universidad de Navarra, Pamplona

Spain

Correspondencia: Concha Iriarte. Campus Universidad de Navarra. Edificio de Bibliotecas. C.P 31009. Pamplona. España. E-mail: ciriarte@unav.es

(C) Education y Psychology I+D+i and Ilustre Colegio Oficial de la Psicología de Andalucía Oriental 


\begin{abstract}
Introduction. Studies stress the importance of emotions in conflict, describing how they influence any mediation process. Resolving conflicts requires emotional abilities and it usually implies emotional learning. One of the main objectives of this paper is to better understand the role of emotions in mediation processes: how they impact this process and what emotional aspects are developed through them. A review of the theoretical framework of mediation related to this specific issue and the results of an emplirical study based on the emotional experience of mediation processes are presented.
\end{abstract}

Method. An ad hoc questionnaire was created in order to assess perceived emotional learning gains after a mediation process. For this purpose, a total of 46 teachers mediators, 33 peer mediators and 23 mediated students participated in the study $(n=102)$.

Results. The questionnaire allowed to study the level of perceived learning gain in two differentiated dimensions: emotional awareness and emotional regulation. All groups (teacher mediators, peer mediators and mediated students) perceived a high level of emotional learning, indicanting the effectiveness of the mediation process. No differences in perceived emotional learning gains were found among groups $(p=.56)$. However, although learning improvements were perceived in both dimensions, the level of perceived learning gain in emotional regulation was significantly higher than that perceived in of emotional awareness $(p=.002)$. On the other hand, a shift from negative to positive emotions during the process of mediation was found in pupils mediated.

Discussion and Conclusion. Mediation is a strategy that promotes emotional learning to all of those who take part in it. This study highlights the importance of mediation processes in developing emotional learning. Two main aspects of emotional learning, which were promoted by mediation, were identified in this study: emotional awareness and emotional regulation. It is considered that learning how to manage emotions should be present in any mediator's training course, since a stable resolution of conflicts depends on an adequated management of emotions.

Keywords: School mediation, Conflict resolution, emotional learning,peer mediator, teacher mediator, mediated students. 


\section{Resumen}

Introducción. Los estudios subrayan la centralidad de las emociones en el conflicto, lo que ha llevado a estudiarlas en relación con el proceso de mediación. Este trabajo realiza una síntesis de las principales investigaciones que abordan esta temática específica y presenta un estudio sobre el aprendizaje emocional autoconsciente asociado al proceso de mediación.

Método. Con el fin de conocer los aprendizajes emocionales autoconscientes tras participar en procesos mediación, se elabora una escala ad hoc y se aplica a una muestra de agentes implicados en procesos de mediación $(n=102)$ de los cuales 46 son profesores mediadores, 33 son alumnos mediadores y 23 alumnos mediados. Asimismo, también se evaluó el cambio de emociones percibidas en los alumnos mediados durante el proceso de mediación.

Resultados. Se evaluó el nivel de aprendizaje emocional autoconsciente en dos dimensiones diferenciadas: conciencia y regulación emocional. En todos los grupos (profesores mediadores, alumnos mediadores y alumnos mediados) se percibió un nivel de aprendizaje emocional alto, lo que parece indicar la efectividad del proceso de mediación. Asimismo, las mejoras percibidas en el aprendizaje emocional no cambiaron en función del grupo evaluado $(p=.56)$. No obstante, si bien en ambas dimensiones se percibieron mejoras, el nivel de aprendizaje autoconsciente en la dimensión de regulación emocional fue significativamente superior al percibido en la dimensión de conciencia emocional $(p=.002)$. Por otro lado, se observó un cambio de emociones negativas hacia positivas en los alumnos mediados al finalizar el proceso de mediación.

Discusión y Conclusión. Los resultados indican que la mediación no sólo es una estrategia que favorece la convivencia general del centro educativo, sino que promueve el aprendizaje emocional de los que participan en ella. En este estudio destacan como los principales aprendizajes emocionales de los tres grupos: el aumento de la conciencia y de la regulación emocional.

Palabras Clave: mediación escolar, resolución de conflictos, alumnos mediadores, alumnos mediados, profesores mediadores, aprendizaje emocional 


\section{Introducción}

"Emotions belong on the negotiating table" (Picard \& Siltanen, 2013, p.62), that is to say, they are present in conflict relations (Bell \& Song, 2005; Friedman et al., 2004; Fisher \& Shapiro, 2005; Jameson, Bodtker \& Linker, 2010; Jameson, Sohan \& Hodge, 2014; Maiese 2006; Murphy \& Eisenberg, 2005; Redorta, Obiols \& Bisquerra, 2006). Indeed, most mediators point out that mediation seems to deal more with the emotions than with the objective facts as stated by the parties in conflict. In this sense, the research reflects the importance of including awareness and emotion-control training in the curricula of school mediators (Jones, 2001, 2006; Murciano \& Notó, 2005, Shapiro, 2006, Villaoslada \& Palmeiro, 2006) and in fact, some mediation programs such as those of Shapiro (2004), Boqué (2007), White \& Agne (2009) and Halperin (2014) specifically do so. As Filella, Pérez, Cabello and Ros-Morente (2016) point out, the development of students' emotional competence brings about a reduction of conflict of situations and avoids the appearance of more serious problems like bullying. In this way, the use of mediation in schools firstly helps to train the students socially and emotionally, and also modifies the social climate of the centres, which, for authors such as Ortega-Ruiz, Del Rey and Casas (2016), not only improves coexistence but also avoids the current bullying problem.

\section{Emotional training: emotional awareness and regulation in the mediation process}

Resolving a conflict requires basic knowledge of how to change the perception of the situation, to challenge existing interpretations or to develop new ones. The mediator must generate new understanding, new interpretative frameworks, and, through dialogue, has to enfranchise the interested parties so they may find new ways of interacting and managed to find new solutions. In this sense, mediation is a learning and transformation process which permits one to break down defences, take risks, create open-mindedness, curiosity and empathy between the parties. This is what is suggested in the model called insight mediation on which our study is based (Melchin \& Picard, 2008; Picard \& Melchin, 2007; Sargent, Picard \& Jull, 2011). The complex learning involved in mediation demands that the mediator show how to recognize underlying emotional patterns which make the conflict permanent. In reality, if at a profound level there is no wish for change, if the postures are defensive and the learning process is blocked, mediation cannot produce true change (Picard \& Siltanen, 2013). 
From this perspective, the emotions become indicators which show the mediator how the reconciliation is advancing, the open-mindedness and degree of empathy between the parties.

The emotions come to the surface mainly in the pre-mediation phase and the presentation of the facts (Villaoslada \& Palmeiro, 2006). Thus, Rozenblum de Horowitz (2007) indicates that in the mediation process there is a first moment -which she defines as "emotional venting"- when the mediator should not repeat the ideas or facts expressed, or paraphrase what each party states, but should simply point out the emotions transmitted by each of the parties in conflict. At the start of the mediation process it is common for people to feel irritated, offended, frustrated, mistrustful, alienated, disheartened, resentful, betrayed, fearful or resigned. It is indispensable that these emotions must be heeded so as not to block the following process.

In the initial phases of the mediation, when the parties in conflict are totally alienated, Fisher \& Shapiro (2005) suggest attending to the following emotions: guilt, shame, remorse, fear, sadness, intimidation, worry and impatience. Picard \& Siltanen (2013) -based on mediators' self-reports- emphasize the following: doubt, frustration, anger, anxiety and shame. Mistreatment of these emotions may produce a lack of effectivity during the process (Shapiro, 2006), therefore this author suggests avoiding the following errors: 1) waiting for emotions to emerge by themselves, 2) believing that once they have been expressed the emotions will disappear, and 3) not taking into account the emotional resistance of the parties throughout the process.

The emotions, in short, are a means to communicate the identity concerns in the relationship and the parties can only reach their objectives through an explicit negotiation of the emotions and concerns generated in the relationship which threaten the identity of the mediated parties (Shapiro, 2002). It is for this reason that it is so important to generate awareness of the emotions between the parties in conflict. The advent, during the process, of emotions such as happiness, pleasure, pride and satisfaction indicate that the conflict is beginning to be resolved (Picard \& Siltanen, 2013) and that emotional regulation is active. 
Key emotions in the emotional awareness and regulation process during the mediation

The emotions which the research points out as being most decisive when it comes to the emotional transformation of the conflict are as follows:

1) Hate, for Halperin (2011), is the highest barrier to be overcome in order to achieve peace as it causes the rejection of any positive information regarding the opponent and blocks negotiations, compromise or reconciliation.

2) Anger is a very significant emotional barrier when it comes to making compromises (Sabucedo, Durán, Alzate \& Rodriguez, 2011; Tam et al., 2007). For Epstein \& Epstein (2010), Lieberman (2006) and Villaoslada \& Palmeiro (2006), anger is an emotion which can increase in intensity as it may rekindle the conflict again and again, leading to increased obsession and stress, and block the possibility of reaching objectives by increasing the perception of injustice and aggravating personal relationships. Mediation can redirect all that angry energy in a positive way if it can be expressed. In fact, containing anger too quickly may make the mediation fail -therefore it is recommendable to redirect it during one or more premediation sessions- but, by the same token, expressing anger openly without guidance blocks the capacity to reach agreement.

Friedman et al. (2004) carried out on line mediation sessions and concluded that the anger expressed by the participants was counterproductive as it produced heated responses and reduced the ratios of conflict resolution. In addition when the person against whom the anger was directed was more vulnerable, it caused him/her to make excessive concessions. For Halperin (2014), anger may be beneficial in the conflict-solving process as it is a focused emotion of great strength which can inspire risky behaviour (implicit in all negotiation processes), optimism and belief that the situation can be reversed. Therefore, anger may improve reconciliations in the long-term, providing that it is not accompanied by hate and has continuity with constructive proposals.

The study by Murphy \& Eisenberg (2002) warns about the relationship between some emotions that arise in the conflict -specifically, sadness and anger- and some aims and behaviours. Through the study of interviews of students who had been involved in conflicts recently, they concluded that the students who felt anger showed antagonistic objectives and desires for revenge together with behaviours that did not favour collaboration for conflict- 
solving. On the other hand, students who felt sadness showed friendly objectives and wishes to normalize the broken-down relationship. However, sadness was not associated with constructive proposals for conflict-solving and could lead to submission.

3) Fear, intergroup anxiety and collective anxiety increase conservatism, prejudices, ethnocentrism and intolerance. They leads to more immovable and defensive positions, although they may also lead towards willingness to make concessions in order to achieve peace (Halperin, 2014). For Epstein \& Epstein (2010) and Lieberman (2006), they are emotions which are found on the verge of mediation. Fear and anxiety stem from uncertainty, the lack of predictability, of self-confidence and control. They generate alarm, concern, restlessness, apprehension and anguish; and the need to free oneself from the discomfort they cause may give way to the home of achieving agreements. A proper reading of this emotion is a key point in mediation strategy.

4) Regarding enthusiasm, Sabucedo et al. (2011) found that this emotion is associated with a potential reduction in risk-evaluation and brings about a more optimistic perspective on the negotiations which can be reached in mediation.

5) Hope, which facilitates the peace process as it is associated with the fixing of objectives, planning, the use of images, creativity, cognitive flexibility and the mental exploration of new situations, even risky ones.

Bell y Song (2005) suggest paying attention, during the mediation process, to four categories of emotions: 1) emotions focusing on oneself or self-conscious emotions (shame, guilt, humiliation); 2) emotions that are hostile to others (anger, frustration, anxiety); 3) emotions with positive correspondence (friendliness, respect, liking) and 4) fear. On this point, for Poitras \& la Tareau (2008): a) integrating or compromising conflict resolution strategies are only related to feelings of positive correspondence emotions, b) hostility correlates significantly with the external assignment of guilt, c) the internal assignment of guilt is related to emotions centred on oneself (self-conscious emotions) and with the selection of submissive conflict-solving strategies which only wish to satisfy the interests of the other party and reflect great concern for others and little concern for oneself. 
This suggests that, although during the conflict the mediators may be motivated to reduce hostility, their efforts should focus on safeguarding the empathic emotions or those of positive reciprocity. In fact, reciprocity is the basis for collaboration between the parties, and, without a point of connection from which the other party is respected, there can be no possible means of communication to express feelings and thoughts or to contrast opinions. Lieberman (2006) points out that when one of the parties realizes that the other has made an effort to change his/her posture, it is more likely that the former will act reciprocally.

\section{Awareness and the emotional regulation of the mediator}

The role played by the mediator in the process of reactivating communication is fundamental as, by means of various communication techniques, he/she offers continuing emotional feedback to the parties involved (Munné \& Mac-Cragh, 2006). The emotions are not generally explicit, but rather are latent in verbal and nonverbal messages, and certain skills are needed to identify them. Active listening not only facilitates this identification, but also the reformulation of the emotional content of the message by using the same words or by paraphrasing, which gives the person an opportunity to check the accuracy of the perception of his/her emotions.

For Jones \& Bodtker (2001) and Bodtker \& Jameson (2001), the mediators must pay attention to three key components of the emotion: behaviour, physiology and cognition. The information coming from the behavioural component of the emotion is easier for the mediators to understand than the physiological or cognitive information, but the former is determinative. An emotional block (flooding) can be seen in muscular tension or the respiratory rhythm and must be dealt with, even when the individual appears to be calm. In addition, subconscious emotional contagion between the parties in conflict and the mediator must be controlled, together with the meta-emotions and the emotional evaluation and re-evaluation by the parties.

The mediator's disposition in the process is also a key element to facilitate emotional change. As Smilovitz (2008) states, the perception that the people in conflict have of the mediator's emotions affects the way in which they will organize, process and use the information. The research (Shreier, 2002, Lund, 2000) suggests how proper training which prepares the mediator to manage strong emotions must include the development of emotional competences in order to 1) increase his/her tolerance to the expression of emotions, 2) devel- 
op impartiality and reduce stress, 3) teach patience and humility, and 4) develop realistic expectations regarding the benefits of mediation.

Shreier (2002) and Epstein \& Silverman (2012) warn that some of the mediator's feelings such as empathy, active listening, confidence, recognition of needs, interests or concerns or the search for justice may lead the mediator to identify with the other person so much that he/she may distort the impartiality which must guide the process. This is why the mediator must reach a level of optimum emotional self-awareness that will help him/her continue objectively without allowing his/her own emotions to interfere. Minkle, Bashir \& Sutulov (2008), in order to work on this and other similar difficulties, propose the creation of peer consultation groups with the aim of generating a space which favours reflection on how the emotions of the mediated parties affect the mediator's own emotions.

Mediation is a difficult learning and personal transformation process during which emotions will spring up; thus, as Epstein \& Silverman (2011, 2012) suggest, the mediator must be capable of generating a space which has to be: a) flexible and understanding of all types of emotions and motivations in order to recognize and unblock pain, b) conciliatory in order to free people from the past, c) honest in order to take people out of their self-protection zone so that they can show themselves as they really are with no masks, d) full of humour and humility to unmask the pride, impatience and pessimism which have caused the conflict and e) where the mediator can empower both parties, re-energize them by removing stress, permit them to connect with their own strengths and cause them to abandon defensive postures in order to connect with their opponents.

Among the research that studies the strategies used by the mediator to favour emotion regulation, we find that by Jameson, Bodtker \& Linker (2010). The researchers carry out a content analysis of simulated mediations and observe the differences between the two groups of mediators. One group was asked to elicit the emotional experience of the parties involved, and the other to ignore or minimize such experience. The results indicate that the first group uses five strategy types, as are: paraphrasing, promoting the emotional awareness of the parties, perspective taking, legitimizing the emotions expressed and interpretation of the emotions of the parties. Their experience suggests: a) being careful that the perspective taking is not felt to be forced and does not arouse mistrust in the other party who may think it is not an authentic process; b) regarding the interpretation of emotions, especially with the 
emotions that the mediated party does not specify, it is important that the mediator do this by means of caucus or individual interviews to avoid embarrassment or provoke reactance and c) use, in this order, strategies of self-awareness, paraphrasing, and perspective taking, which generate more significant emotional changes. For Charkoudian, De Ritis, Buck and Wilson (2009), the two strategies used most frequently by mediators in order to transform emotions in mediations are: 1) summarizing or paraphrasing feelings previously mentioned by the participants and 2) revising the participants' probable sentiments.

Apart from those mentioned above, the strategy of cognitive re-evaluation has been proven to reduce aggression and to increase conciliatory attitudes up to five months after receiving training (Halperin \& Gross, 2011), it leads to redress for the victim; promotes feelings of group guilt; by changing beliefs regarding the threat, it also reduces intergroup anxiety and increases the motivation for interaction and communication with the groups in conflict. Poitras (2007) likewise confirms that leading the parties to accepting their own guilt favours reconciliation.

But apart from these direct strategies used in the mediation process, Halperin (2014), Maoz (2011) and Paluck (2009) suggests the use of others with ecological impact and indirect regulation such as the use of the media to bring the parties together, dialogue groups, plays and novels that deal with these issues or education programs for peace which usually reduce intergroup hate, fear, anger and promote friendliness between groups and a hope to stop the conflict.

\section{Objetivos e hipótesis}

The objective of this research was to analyse and assess the main emotional learning seen by the mediating teachers, the mediating students and the mediated students after participating in mediation processes. It was hoped that those who participated in mediation processes would learn a set of emotional skills for the resolution of conflicts, which, once learned, could be transferred to other areas and broader social networks. This then underlines, in accordance with the stated theoretical framework, the transforming capacity of mediation, specifically its capacity to affect people's emotional development. Therefore, the general hypoth- 
esis proposed was the existence of an improvement in the emotional self-awareness of the participants in the mediation processes.

\section{Method}

\section{Participants}

The Department of Education of the Government of Navarra (Spain) through the Asesoría de Convivencia facilitated the list of schools who were using scholar mediation. 23 centres had received courses in mediation and problem-solving training. Finally 13 schools were chosen from amongst the 23 as the remainder had either not carried out to any mediation processes with students or those which had been carried out were very informal. Therefore at the start of the data-gathering, 13 Navarrese schools made up the acceptance sample for accessibility as they fulfilled the following inclusion criteria: 1) having carried out formal mediation processes for at least a year and 2) also having a peer mediation service. Once the participating schools had been defined, we contacted them and asked them to participate with the maximum possible number of teacher mediators, student mediators and mediated students.

Finally the sample was made up of teacher mediators $(n=46)$, student mediators $(n=33)$ and mediated students $(n=23) .71 .8 \%$ of the teacher mediators were over the age of 40 . Both groups of students were between the ages of 13 and 18. It is worthwhile mentioning the sample of teacher mediators was the broadest and most accessible. In almost all the schools there was a small group of teachers or at least one or two people who had been trained in mediation and were willing to participate. Secondly, the sample of student mediators registered mortality for the following reasons: the school decided that only some of its student mediators should participate so as not to hinder the everyday working of the centre; some student mediators decided not to participate or were absent due to illness or lack of time. Finally the group of mediated students, despite being the largest group in the initial sample, showed the highest mortality. In some cases the parents of the mediated students did not give their authorization for their children to take part in the study and in other schools confidentiality took precedence and the decision was made not to call on them.

\section{Instruments}

The Emotional Learning Scale (Ibarrola-García \& Iriarte, 2012). As no questionnaires were found that fulfilled the proposed objectives, we decided to draw them up, on the basis of the theoretical framework on the empowerment of school mediation (insight mediation) 
(Melchin \& Picard, 2008; Sargen, Picard \& Jull, 2011). After a long and thorough development process, its content was validated in accordance with the theoretical basis and moreover was submitted to expert judgment. After this revision the wording of a total of two items was modified. Subsequently the scale was given to a group of 15 students to test if they understood all the questions correctly and to ensure that none of them was overly discriminatory. In addition, its time of implementation was evaluated. After this implementation, the wording of some items was revised. A total of 10 items scoring on a Likert-type scale (I don't identify with this, I don't identify much with this, I more or less identify with this, I identify a lot with this, I identify completely with this) made up the measurement tool used in this study. Annex 1 shows the list of items presented to the subjects.

Table 1. Aspects related to the emotional learning evaluated on the scale

\section{Emotional learning}

1. Mediation has helped me to be aware of my negative emotions

2. Mediation has helped me realize that my emotions affect how I behave

3. Mediation has helped me to realize that sometimes there are differences between the emotions I feel and what I think my values are

4. Mediation has helped me to better control negative emotions (their causes, consequences, intensity and duration)

5. Mediation has increased my patience with problems

6. Mediation has helped me to tell others if they have behaved unfairly

7. Mediation has helped me to better understand other people's points of view

8. Mediation has helped me to recognize emotions in others' gestures, movements or expressions

9. Mediation has helped me to better express my needs, feelings or emotions in relation to others

10. Mediation has helped me to communicate better with others 
By means of this scale, it is intended to discover to what extent the people who have participated in mediation notice emotional learning. It offers an estimation on the reflexive aspects of the experience for the teacher mediators, student mediators and mediated students. After a validity analysis of the data obtained on an exploratory basis, the items which could not be assigned to any of the factors found were eliminated. The analytical method used was the factor analysis of principal components. The suitability of the application of this method to the survey sample was established by means of the Kaiser-Meyer-Olkin Test for Sampling Adequacy and Bartlett's sphericity test. Due to the presence of correlation between the different factors found on the scale, the method of rotation used for this analysis was that of oblique rotation, opting for the application of the Promax method. All items presented a communality superior to 0.40 . For reliability, in order to estimate the internal consistency Cronbach's alpha was used for each of the factors found.

The Kaiser-Meyer-Olkin Test for Sampling Adequacy $(\mathrm{KMO}=0.872)$ and Bartlett's sphericity test $(p<.001)$ produced satisfactory results, demonstrating that the sample was suitable to carry out the factor analysis. Of the 10 initial items, two (items 4 and 5) were eliminated after the analysis as they presented correlation and a very similar factor load to the factors found. Finally, an 8-item tool with a 2-factor structure (which presented autovalues superior to 1) was obtained which explained approximately $64 \%$ of the variance. The first factor (Factor 1) was made up of 5 items (items 1, 2, 3, 6 and 8) shown in the Annex and the second (Factor 2) by 3 (items 7, 9 and 10 shown in the Annex).

The factors have been denominated emotional awareness (Factor 1) and emotional regulation (Factor 2). The first, emotional awareness, refers to the capacity to identify and recognize both one's own feelings and those of others. This implies paying attention to and precise decoding of the emotional signs in facial expressions, body language and tone of voice. Being aware of the interaction between emotion, cognition and behaviour. Finally, this scale involves the faculty of correctly recognizing the honesty and sincerity of the emotions expressed by others (Mayer, Salovey \& Caruso, 2009; Bisquerra, 2009; Fernández-Berrocal, 2005).

The second has been denominated emotional regulation, and refers to the capacity of appropriately expressing emotions, regulating one's own emotions and those of others and also generating emotions by moderating negative ones and intensifying positive ones. It involves the capacity of understanding that the internal emotional state does not necessarily 
correspond to the external expression, both in oneself and in others. At higher levels of maturity, it means understanding the impact that one's own emotional expression and behaviour may have on other people. It also includes the habit of taking this into account in relationships with others (Mayer, Salovey \& Caruso, 2009; Bisquerra, 2009; Fernández-Berrocal, 2005). The internal consistency of the general 8-item test was $\alpha=0.875$, and for each of the factors was as follows: Factor 1 (emotional awareness), $\alpha=0.848$; Factor 2 (emotional regulation), $\alpha$ $=0.735$, showing satisfactory values in all cases.

Emotions during the mediation process (Ibarrola-García y Iriarte, 2012). Apart from these items two nominal questions were included related with the identification of emotions during the mediation process. Specifically, the teacher mediators and the pupil mediator were asked to point out from a list of emotions those which the students implied in the conflict had at the beginning of the mediation process and at the end. And the mediated students were asked to point out on the same list the negative emotions that they felt on attending the mediation together with the positive ones on finalizing the process.

For the validation of this tool, a new factor analysis was carried out with an exploratory aim. In this case, in order to carry out the analysis, each of the emotions presented was considered as a separate item with the possibility of a binary response (Yes/No). As in the previous case, the adequacy of the application of this method to the survey sample was established by means of the Kaiser-Meyer-Olkin Test for Sampling Adequacy and Bartlett's sphericity test. Bartlett's sphericity test $(p<.001)$ gave satisfactory results, while the Kaiser-MeyerOlkin Test for Sampling Adequacy $(\mathrm{KMO}=0.111)$ showed that carrying out a factor analysis with the sample data gathered was not adequate. Moreover, the anti-image correlation matrix supported this result, showing excessively low correlations ( $r=<.316$ in all cases) in the matrix diagonal and elevated correlations in the remainder of the same. These results suggest that carrying out a factor analysis is not adequate for the set of data gathered with this tool, and might not give stable and replicable results in other samples, so finally this analysis was not carried out. For this reason the results obtained with this tool should be validated in further studies.

For the analysis of the reliability of the test the Kuder-Richardson 20 coefficient was calculated; this is a measure of internal consistency for binary items. This measure is a special case of the Cronbach's alpha coefficient and is interpreted in a similar way (Kuder \& Rich88 - 
ardson, 1937). In this case, the internal consistency obtained was KR-20 $=-6.749$, which shows a negative value and demonstrates a total lack of internal consistency in the tool used.

As we have commented, the tool used to recognize the emotions of mediated students during the mediation process did not show satisfactory values for either its validity or its reliability. One possible explanation for these results is that, when presenting the scale, the subjects were told they could mark only a maximum of three negative emotions and a maximum of three positive emotions from among all the emotions presented. Therefore, the fact of having considered each emotion as a different item with a possible binary response in the analysis of validity and reliability carried out may not have been the most appropriate option, as it does not respond completely to the reality in which the data was gathered. As can be seen in this explanation, in no case could more than six emotions be recognized in the mediated students, which undoubtedly would affect the internal consistency index of the tool. Consequently, we recognize that, in order to confirm the results obtained in this study, the tool used must be validated in future research. To do so, it is proposed that in subsequent versions of same, the number of emotions which may be recognized by the participants should not be limited. For this reason, the tool was only used to calculate the percentage of subjects in each group who identified of the emotions presented.

\section{Procedure}

On the basis of a cross-sectional design, the application of the scale and gathering of data were carried out in each of the schools individually over a period of four months. The researcher visited each of the schools to have a meeting with the principal and the individuals he/she summoned. At this meeting an explanation was given of the aim of the research, why it was of interest and how they could be of assistance. After this initial meeting, 13 schools agreed to participate and a date was agreed on for the researcher to return to apply the scale. A letter was written in Spanish and in Basque to ask the parents' permission for their children to participate in the research. In the cases where this permission was given, the data-gathering was carried out. During the application of the scale to the students, the researcher laid particular emphasis on solving any doubts and on giving the indications correctly, in order to avoid introducing any bias in the responses in as far as possible. 
The data-gathering procedure had the approval of the Asesoría de Convivencia del Gobierno de Navarra. Moreover, the Ethics Commission of the University of Navarra gave its backing to the proper use of the data gathered in this research.

\section{Data analysis}

The independent variable of the study is the type of participant in the mediation process (teacher mediator, student mediator and mediated student). There are two dependent variables in the study: 1) perception of self-aware emotional learning and 2) identification of emotions during the mediation process.

Firstly, a descriptive analysis of each of the factors identified on the scale of emotional learning was carried out. In order to assess whether there were significant differences between the punctuations given by the subjects to the different factors, and between the different study groups, a factorial ANOVA was used with these factors: 1) Intra-subject: Factor on the scale (emotional awareness, emotional regulation) and 2) Inter-subject: Group (Teacher Mediator, Student Mediator, Mediated Student). The requirements of normality were fulfilled in the residuals and homogeneity of variances required in order to apply this analysis.

With reference to the study of emotions during the mediation process, firstly the percentage of subjects in each group who recognized each of the emotions presented were identified. Subsequently, in order to identify significant differences between the three study groups (Teacher Mediator, Student Mediator, Mediated Student), the Chi-squared test was used for the comparison of proportions in independent groups. For the proportion comparison in independent groups. This test was applied for each of the 26 emotions presented and subsequently the Bonferroni correction was applied to the $p$ values obtained. In those cases where significant differences were found between the groups, 2 to 2 comparisons were repeated in order to identify the groups in which the differences were found. In this case the Bonferroni correction to the values of $p$ obtained was reapplied. The level of significance was fixed at $\alpha=.05$ for all the analyses. The SPSS program, version 15.0 was used for statistical treatment. 


\section{Results}

\section{Emotional learning}

\section{Emotional learning in mediated students and student and teacher mediators}

Figure 1 shows the distribution of emotional learning scores in the three study groups -teacher mediator (first column), student mediator (second column) and mediated student (third column)- for each of the factors evaluated with the tool.

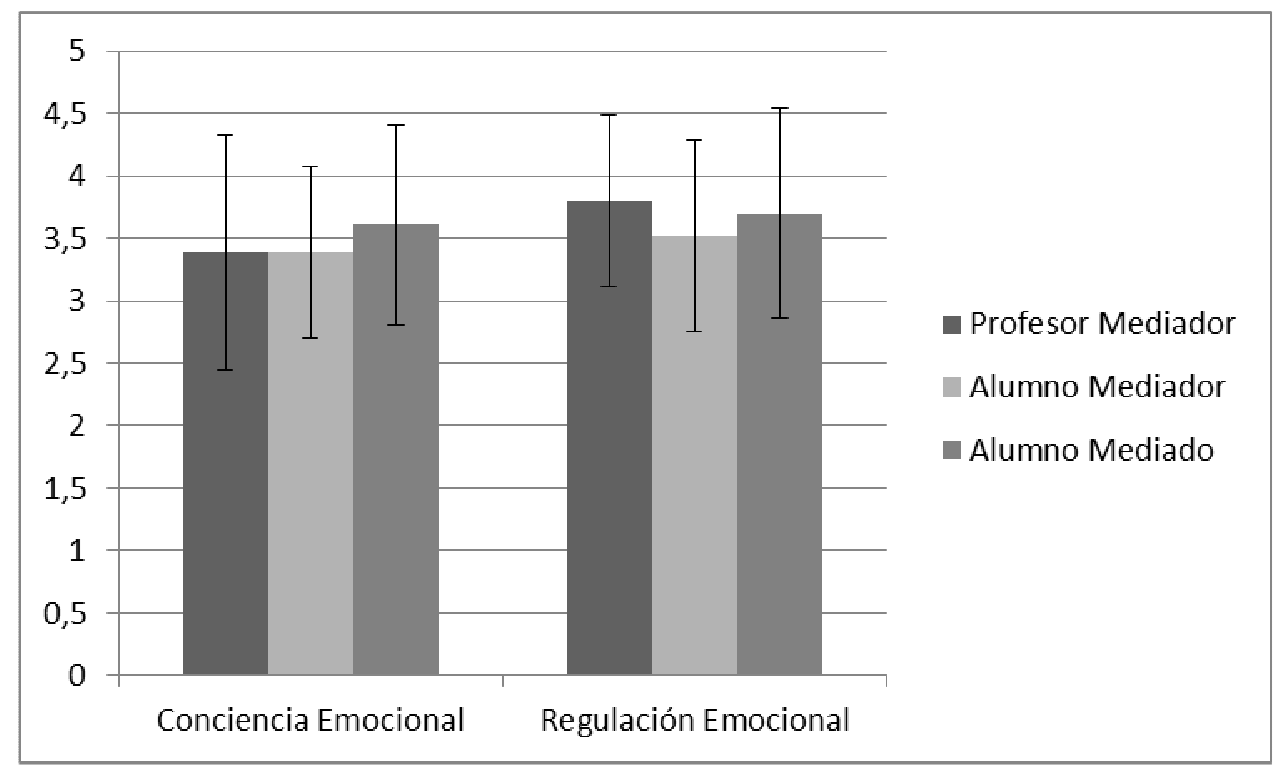

Figure 1. Distribution of the scores on emotional learning items (Mean \pm standard deviation)

Through the Factorial ANOVA, no significant interaction was found $[F(2,99)=2.52$, $p=.086 ; n^{2}=0.048$ ] between the Factor Scale variables (Emotional awareness, Emotional regulation) and Group (Teacher Mediator, Student Mediator, Mediated Student)). For this reason the principal effects on each of the variables studied were evaluated.

No significant differences were found in the mean scores of the scale between the different study groups $\left(F(2,99)=0.58, p=.56, n^{2}=0.012\right)$ (see Table 1$)$, which indicates that the level of emotional learning received through the process of mediation was equivalent in both teacher mediators and student mediators and mediated students. In all the groups high mean scores of emotional learning were given (over 3.38 in all cases), which seems to indicate the effectiveness of the mediation process. 
Besides, significantly higher scores were found in the emotional regulation Factor $(M=3.69, S D=0.75)$ than in the emotional awareness Factor $(M=3.43, S D=0.83)$ in all groups $\left(F(1,99)=10.13, p=.002, n^{2}=0.093\right)$ (see Table 1$)$. These results indicate that the selfawareness learning and the emotional regulation dimension were significantly higher than was seen in the dimension of emotional awareness.

Table 2. Descriptive statistics obtained dependent on the groups and factors evaluated

\begin{tabular}{|c|c|c|c|}
\hline & Groups & Mean & $\begin{array}{c}\text { Standard devia- } \\
\text { tion }\end{array}$ \\
\hline \multirow[t]{4}{*}{ Mean Total Scale } & $\begin{array}{c}\text { Teacher } \\
\text { mediator } \\
(\mathrm{n}=46)\end{array}$ & 3.55 & 0.79 \\
\hline & $\begin{array}{l}\text { Student } \\
\text { mediator } \\
(\mathrm{n}=33)\end{array}$ & 3.45 & 0.68 \\
\hline & $\begin{array}{c}\text { Mediated } \\
\text { student } \\
(\mathrm{n}=23)\end{array}$ & 3.69 & 0.73 \\
\hline & $\begin{array}{l}\text { All the } \\
\text { groups }\end{array}$ & 3.55 & 0.74 \\
\hline \multirow[t]{4}{*}{$\begin{array}{c}\text { Mean ítems Factor } \\
1 \text { - Emotional } \\
\text { awareness }\end{array}$} & $\begin{array}{l}\text { Teacher } \\
\text { mediator }\end{array}$ & 3.38 & 0.94 \\
\hline & $\begin{array}{l}\text { Student } \\
\text { mediator }\end{array}$ & 3.38 & 0.69 \\
\hline & $\begin{array}{c}\text { Mediated } \\
\text { student }\end{array}$ & 3.60 & 0.80 \\
\hline & $\begin{array}{l}\text { All the } \\
\text { groups }\end{array}$ & 3.43 & 0.83 \\
\hline \multirow[t]{4}{*}{$\begin{array}{c}\text { Mean items Factor } \\
2 \text { - Emotional } \\
\text { regulation }\end{array}$} & $\begin{array}{l}\text { Teacher } \\
\text { mediator }\end{array}$ & 3.80 & 0.69 \\
\hline & $\begin{array}{c}\text { Student } \\
\text { mediator }\end{array}$ & 3.53 & 0.77 \\
\hline & $\begin{array}{c}\text { Mediated } \\
\text { student }\end{array}$ & 3.70 & 0.84 \\
\hline & $\begin{array}{l}\text { All the } \\
\text { groups }\end{array}$ & 3.69 & 0.75 \\
\hline
\end{tabular}

\section{Emotions during the mediation process}

There is full concurrence regarding the emotions pointed out by the student mediators and mediated students at the start of the mediation (see results in Table 3). The negative emotions most frequently presented by the mediated students on beginning the mediation processes are according to the student mediators: mistrust (73\%), nervousness (61\%) and shame (52\%). On the other hand, the mediated students emphasize, among the emotions they bring to the mediation: mistrust (52\%) and nervousness (57\%), although they do mention shame $(26 \%)$, sadness (22\%) and guilt (22\%) also. 
At the same time, the student mediators indicate that the positive emotions of those mediated at the end of the mediation process are: satisfaction (73\%), tranquillity (52\%) and hope $(46 \%)$. Moreover, a high percentage $(78 \%)$ of the mediated students stated that they felt calm after the process and to a lesser extent (57\%) satisfaction. In addition, a good deal of agreement was seen on identifying the emotions of the mediated students according to the teacher mediators. The former mainly attend the sessions with hostility and resentment $(61 \%$ and $50 \%$ respectively), and to a lesser extent mistrust and anger (44\% and $28 \%$ respectively). After the mediation the teachers agreed that the students feel satisfaction, tranquillity and confidence; almost $70 \%$ of the teachers coincide in pointing out these emotions.

Table 3. Percentage of teacher mediators, student mediators and mediated students who identify different negative emotion in the mediated students

\begin{tabular}{|c|c|c|c|c|c|c|c|}
\hline & $\begin{array}{l}\text { Teacher } \\
\text { mediator }\end{array}$ & $\begin{array}{l}\text { Student } \\
\text { mediator }\end{array}$ & $\begin{array}{l}\text { Mediated } \\
\text { student (of } \\
\text { him/herself) }\end{array}$ & & $\begin{array}{l}\text { Teacher } \\
\text { mediator }\end{array}$ & $\begin{array}{l}\text { Student } \\
\text { mediator }\end{array}$ & $\begin{array}{l}\text { Mediated } \\
\text { student (of } \\
\text { him/herself) }\end{array}$ \\
\hline Mistrust & $43.48 \%$ & $72.7 \%$ & $52.2 \%$ & Fear & $17.4 \%$ & $15.1 \%$ & $13 \%$ \\
\hline Nervousness & $36.96 \%$ & $60.1 \%$ & $56.5 \%$ & Hostility & $60.9 \%$ & $12.1 \%$ & $13 \%$ \\
\hline Shane & $4.35 \%$ & $51.5 \%$ & $26.1 \%$ & Satisfaction & $69.6 \%$ & $72.7 \%$ & $52.2 \%$ \\
\hline Sadness & $8.7 \%$ & $3.03 \%$ & $21.7 \%$ & Tranquillity & $69.5 \%$ & $51.5 \%$ & $78.3 \%$ \\
\hline Guilt & $4.35 \%$ & $6.06 \%$ & $21.7 \%$ & Hope & $37 \%$ & $45.45 \%$ & $17.4 \%$ \\
\hline Anger & $28.3 \%$ & $18.2 \%$ & $13 \%$ & Happiness & $2.2 \%$ & $24.2 \%$ & $21.7 \%$ \\
\hline Resentment & $50 \%$ & $12.1 \%$ & $17.4 \%$ & Pride & $10.9 \%$ & $6 \%$ & $8.7 \%$ \\
\hline Irritation & $32.6 \%$ & $27.3 \%$ & $4.3 \%$ & Friendship & $2.1 \%$ & $12.1 \%$ & $8.7 \%$ \\
\hline Frustration & $13 \%$ & $9.1 \%$ & $4.3 \%$ & Interest & $19.6 \%$ & $21.1 \%$ & $17.4 \%$ \\
\hline Envy & $0 \%$ & $9 \%$ & $8.7 \%$ & Good humour & $2.2 \%$ & $21.1 \%$ & $17.14 \%$ \\
\hline
\end{tabular}


The statistical analyses showed that, in general, both the teacher mediators and the two student groups identified the emotions felt by the mediated students during the mediation process in a similar way. These results seem to indicate that this type of process permits adequate identification of the emotions of the mediated students.

The emotions which showed significant differences between groups were the following: resentment $\left[\chi^{2}(2,102)=15.41, p<.05\right]$, hostility $\left(\chi^{2}(2,102)=26.22, p<.05\right)$, shame $\left(\chi^{2}(2\right.$, $102)=23.14, p<.05)$ and confidence $\left(\chi^{2}(2,102)=13.02, p<.05\right)$ (see Figure 2$)$. The significant differences were found in all cases between the teacher mediators and the students, both mediators and mediated. In no case were significant differences found between the two student groups, which seems to indicate that the student mediators are more capable of perceiving the emotions of the mediated students during the mediation process than are the teacher mediators. In the identification of the emotions of resentment, hostility and confidence there was a significantly higher percentage of teachers $(50 \%, 60.9 \%$ and $69.6 \%$ respectively) than of student mediators (Resentment: $12.1 \%, \chi^{2}(1,79)=12.26, p<.05$, corrected by Bonferroni; Hostility: $12.1 \%, \chi^{2}(1,79)=18.95, p<.05$, corrected by Bonferroni; Confidence: $36.4 \%, \chi^{2}(1$, $79)=8.58, p<.05$, corrected by Bonferroni) and mediated students (Resentment: $17.4 \%, \chi^{2}(1$, N69) $=6.85, p<.05$, corrected by Bonferroni; Hostility: $13 \%, \chi^{2}(1,69)=14.18, p<.05$, corrected by Bonferroni; Confidence: $30.4 \%, \chi^{2}(1,69)=9.55, p<.05$, corrected by Bonferroni) who mentioned them during the mediation process (see Figure 2). On the contrary, a significantly lower percentage $(4.4 \%)$ of teachers than of student mediators $\left(51.5 \%, \chi^{2}(1,79)=23.40, p<.05\right.$, corrected by Bonferroni) and those mediated $\left(26.1 \%, \chi^{2}(1,69)=7.07, p<.05\right.$, corrected by Bonferroni), identify shame as part of the mediation process. 


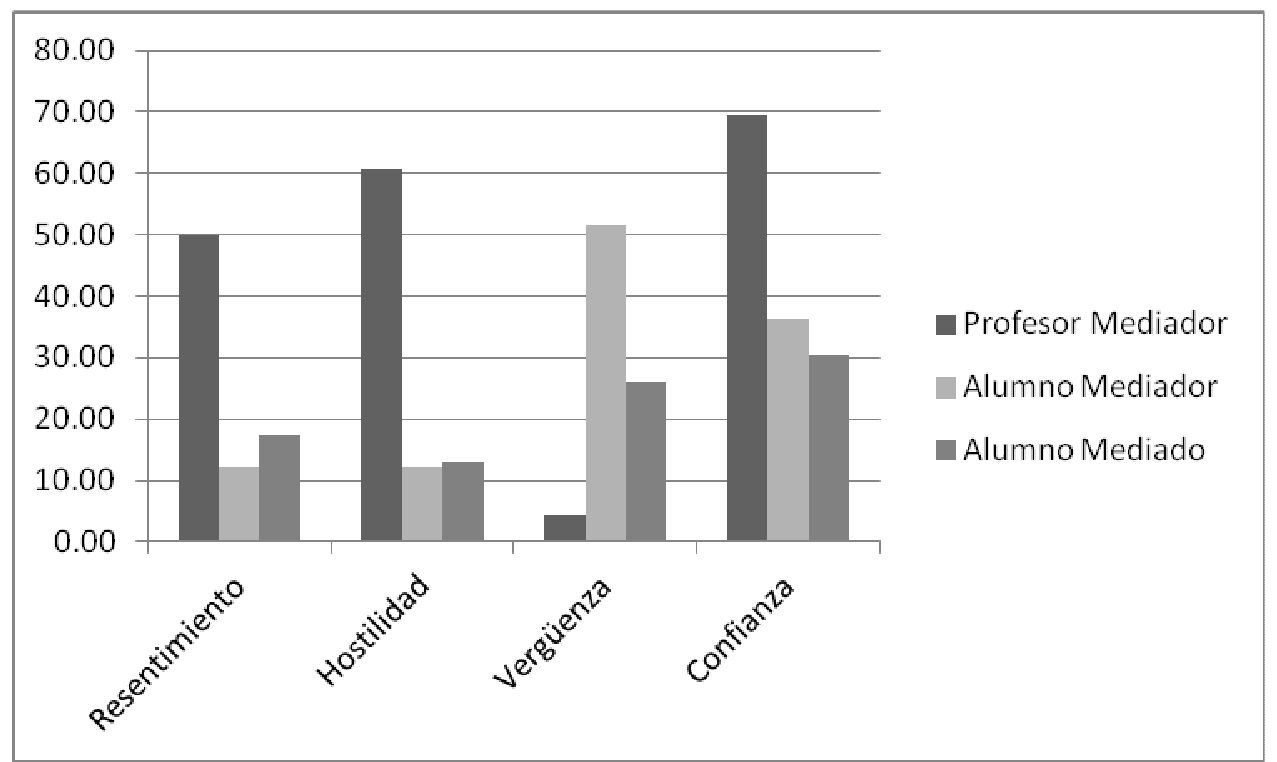

Figura 2. Percentage of subjects who identify the emotions of resentment, hostility, shame and confidence in each of the groups (teacher mediators, student mediators and mediated students).

Note. These emotions correspond to those for which significant differences were found between groups. In all cases significant differences were found between teacher mediators and students, both mediators and mediated ( $p<.05$, with Bonferroni correction).

\section{Discussion and conclusions}

Mediation is a process that generates emotional, social and moral learning (Ibarrola-García y Iriarte, 2012). With reference to the emotions, based on this research we can say that all the participants in mediation coincide in pointing out an increase in emotional awareness, specifically: detection of negative emotions, influence of the impact of the emotions on behaviour, discordance between cognition, emotion and values, recognition of the honesty of emotions and recognition of emotions in others' gestures, body language or expressions.

These data are congruent with prior evidence, which underlines emotional awareness as the starting point to unblock the communicative process which occurs during the mediation (Gutenbrunner \& Wagner, 2016, Goldstein, Vezich \& Shapiro, 2014). If a person is not aware of his/her own emotions, of what they are and the influence they have, it is difficult to express how one feels, what one thinks and so unblock the communicative process. This is why the mediator points out the emotions that each party transmits at the beginning of the mediation (Rozenblum de Horowitz, 2007). At the same time this initial conflict-clarification phase in 
which the parties express themselves is necessary in order to become aware of the other's emotions. Moreover this initial phase of clarification of the conflict when the parties express themselves is essential in order to be aware of the other's emotions. Thus when emotional awareness appears, both of oneself and of the other, empathy is created.

This demonstrates that the awareness of emotions is a preliminary step for the development of empathy. Empathy, as a friendly emotional reaction to the emotions of the other party, follows necessarily from acknowledging emotions and is more easily favoured if, in addition to taking into account the other's viewpoint, one feels that one's own has been considered. (Goldstein, Vezich \& Shapiro, 2014).

Likewise, this study allows us to state that the people involved in mediation have seen improvements in their emotional regulation, even more than in their emotional awareness, specifically in emotional comprehension, expression and communication.

Both the teacher mediators and the mediator and mediated students stress that mediation has helped them to better understand other people's perspectives. This same perception has also been seen in other studies. Selfridge (2004), in an assessment of the mediation program carried out in a school in New York, pointed out that $86 \%$ of the teacher mediators underlined the capacity to listen to others as a key improvement developed through their work as mediators.

Long, Fabricius, Musheno \& Palumbo (1998) also found improvements in the empathy of the student mediators between the ages of 8 and 14, although the differences in the post-test were only significant in the group of 10 to 11-year-old students. In addition, LaneGaron \& Richardson (2003) concluded that the impact in the improvement of empathy is greater in the student mediators than in the other participants in the mediation. They demonstrated this by means of a pre- and post-test study of a sample of 300 students aged between 13 and 14.

Furthermore, emotional regulation, in oneself and in others, during conflict-solving has been considered crucial in order to focus attention on the possibilities of improving relationships with the other party. Thus, those people who control the expression of their negative emotions, who use cognitive re-evaluation in conflict of situations, or who have a greater fa- 
cility to change their emotions, have more success in reducing their susceptibility and frustration and in redirecting communications with the opposing party (Jiang, Zhan \& Tjosvold, 2013).

The results suggest an emotional empowerment for those implied in the mediation. In this sense, it can be assumed that this learning goes beyond the close circle of the people in conflict. Thus the mediation reaches a compromise with the milieu as it permits a transfer of what has been learned, taking into account moreover, that many of the conflicts have their origin outside the school environment. It is then a means of socialization as it contributes a sense of community that contrasts with individualism, which may not be taken into account in other forms of conflict-solving (Bickmore, 2001; Cowie \& Fernández, 2006).

In line with our results, other studies, in this case on the figure of the mediator, have already shown that he/she transfers the skills acquired in mediation to his/her milieu (Akgün, Araz \& Aradag, 2007; Bell \& Song, 2005; Lane-Garon, Ybarra-Merlo, Zajac \& Viera, 2007). This increase in the generalization of social conducts oriented to mediation has also been observed in the figure of the mediated party (Del Álamo \& Gómez, 2005) when they confirmed less violent conduct in schools by resolving conflicts between students. And Harris (2005) stressed the use of knowledge, attitudes and skills by the mediated students in other conflictive situations. Using the scale, the students could identify the skills used by the mediators in the mediation process: active listening, speaking calmly and clarification of the information. Thus the mediated students learned skills needed to solve conflicts, partly due to the modelling carried out by the mediator during the process.

\section{Limitations and prospects of the research}

This piece of research has a series of limitations as it evaluates self-aware learning, that is, the knowledge the people surveyed have of their own skills and not of their real capacities. With time, there may be a possibility of carrying out research which would precisely evaluate emotional improvements by means of tests which assess skill. In addition, prospectively, it could be of interest to analyse these indicators in intergroup conflicts. Although there is little research available concerning interpersonal conflicts, there is even less on intergroup conflicts. Carrying out mediation processes for intergroup conflicts may not merely reduce prejudice between the members of the groups but might also favour positive group attitudes and improve relationships between groups. 
Besides, although this work has been carried out in a specific Spanish community and may have a locally-focused touch, we consider that the fact that the procedure used in mediation is universal and means that the data may be transferable to other culturally similar communities.

\section{Implications for the intervention}

1) The emotions are part of every mediation process, therefore it is necessary to train emotionally competent mediators: tolerant of the expression of emotions, aware of their own emotions, capable of understanding the emotions of others and the consequences of said emotions on the conflict. Inasmuch as training in school mediation should deal with these aspects in the form of contents for future mediators and/or for the student body in general, those who are involved in school mediation would be better prepared to manage the process and it would be more likely to finish successfully.

2) In the light of the literature inspected, the emotions which must be controlled in the mediation process because of their negative effect are: mistrust, nervousness, shame, sadness, guilt, hostility and resentment. The emotions which have been shown to be indicators of the transformation of the conflict and of emotional learning and which, therefore, should be fostered are: satisfaction, tranquillity and hope.

3) In turn, in the mediation process, apart from reducing the intensity and number of negative emotions, the mediator should focus particularly on safeguarding positive reciprocity emotions.

4) Regarding the strategies to be used in mediation, apart from those of an intrapsychic nature or direct regulation such as paraphrasing, emotional self-awareness, perspective taking, legitimation and interpretation of emotions or cognitive re-evaluation, we must contemplate other strategies for indirect regulation of an ecological nature such as the use of the media, dialogue groups, theatre, literature and educational peace programs.

5) Implementation of mediation projects in schools may be an effective educational measure both for coexistence and the emotional development of those involved. 


\section{References}

Bell, C., \& Song, F. (2002). Emotions in the conflict process: an aplication of the cognitive appraisal model of emotions to conflict management. The International Journal of Conflict Management, 16(1), 30-54. http://dx.doi.org/10.1108/eb022922

Akgün, S., Araz, A. \& Aradag, S. (2007). We can resolve our conflicts: a conflict resolution program and its psycho-social effects. Turk Psikologi Dergisi, 22(59), 63-67.

Bell, C., \& Song, F. (2005). Emotions in the conflict process: an aplication of the cognitive appraisal model of emotions to conflict management. The International Journal of Conflict Management, 16(1), 30-54. http://dx.doi.org/10.1108/eb022922

Bickmore, K. (2001). Sutdent conflict resolution, power "sharing" in schools, and citizenship education. Currículo Inquiry, 31(2), 137-162.

Bisquerra, R. (2008). Educación para la ciudadanía y convivencia: el enfoque de la educa ción emocional. Madrid: Wolters Kluwer.

Bisquerra, R. (2009). Psicopedagogía de las emociones. Madrid: Síntesis

Bodtker, A., \& Jameson, J. K. (2001) Emotion in conflict formation and its transformation. The International Journal of Conflict Management, 12(3), 259-275 http://dx.doi.org/10.1108/eb022858

Boqué, C. (2007). Guía de mediación escolar: programa comprensivo de actividades de 6 a 16 años. Barcelona: Octaedro.

Charkoudian, L.C., De Ritis, R., Buck, C., \& Wilson, L. (2009). Mediation by any other name would smell as sweet or would it? The struggle to define mediation and its various approaches. Conflict Resolution Quartley, 26(3), 293-316. doi: 10.1002/crq.234

Cowie, H. and Fernández, F.J. (2006). Ayuda entre iguales en las escuelas: desarrollo y retos [versión electrónica]. Revista Electrónica de Investigación Psicoeducativa, 9(2), 291310.

Del Álamo, L. and Gómez, J. (2005). Impacto de un taller de mediación para formar ciudadanos mediadores educativos para la resolución de conflictos interpersonales en contextos de educación secundaria obligatoria. [Documento extraído el 20 de Agosto de 2008 del sitio web del Concejo Educativo de Castilla y León: http://www.concejoeducativo.org/IMG/doc/intervencion_adolescentes_IESZorrilla.do c] 
De Diego Vallejo, R., \& Guillén Gestoso, C. (2008) (2 ed.). Mediación: proceso, tác-ticas y técnicas. Madrid: Pirámide.

Dougherty, L.R. (2006). Children's emotionality and social status: a meta-analityc review. Social Development, 15(3), 394-417. doi: 10.1111/j.1467-9507.2006.00348.x

Epstein, J., \& Epstein, S. (2010). Grief, anger and fear in mediation. Trial Talk, 37-40.

Epstein, J., and Silverman, A. (2011). Alternative dispute resolutions. Reflection IV. Trial Talk, 60(2), 37-41

Epstein, J., \& Silverman, A. (2011). Alternative dispute resolutions. Reflection VII. Trial Talk, 60(2), 33-37.

Fernández-Berrocal, P. F., \& Pacheco, N. E. (2005). La Inteligencia Emocional y la educa ción de las emociones desde el Modelo de Mayer y Salovey. Revista interuniversitaria de formación del profesorado, 54, 63-94.

Filella, G., Pérez, N., Cabello, E., \& Ros-Morente, A. (2016). Evaluación del programa de Educación Emocional “Happy 8-12” para la resolución asertiva de los conflictos entre iguales. Electronic Journal of Research in Educational Psychology, 14(3), 582-601. [http://dx.doi.org/10.14204/ejrep.40.15164]

Fisher, R., \& Shapiro, D. (2005). On being prepared: prepare on process, substance, and emo tion. En R. Fisher y D. Shapiro, Beyond Reason: using emotions as you negotiate (pp.169-182). USA: Penguin Books.

Friedman, R., Anderson, C., Brett, J., Olekalns, M., Goates, N., \& Lisco, C. (2004). The positive and negative effects of anger on dispute resolution: evidence from electroni cally mediated disputes. Journal of Applied Psychology, 89(2), 369-376. http://dx.doi.org/10.1037/0021-9010.89.2.369

Goldstein, N.J., Vezich, S. \& Shapiro, J.R. (2014). Perceived perspective taking: when oth ers walk in our shoes. Journal of Personality and Social Psychology, 106(6), 941-960. doi: $10.1037 / \mathrm{a} 0036395$

Gutenbrunner, L. \& Wagner, U. (2016). Perspective-Taking Techniques in the Mediation of Intergroup Conflict. Peace and Conflict: Journal of Peace Psychology, 22(4), 298305. http://dx.doi.org/10.1037/pac0000184

Halperin, E. (2014). Emotion, emotion regulation and conflict resolution. Emotion Review, 6, 1 (January), 68-76. doi:10.1177/1754073913491844

Halperin, E. \& Gross, J.J. (2011). Emotion regulation in violent conflict: reappraisal, hope, and support for humanitarian aid to the opponent in wartime. Cognition y Emotion, 25, 1228-1236. DOI: 10.1080/02699931.2010.536081 
Harris, R.D. (2005). Unlocking the learning potencial in peer mediation: an evaluation of peer mediation modelling and disputant learning. Conflict Resolution Quartley, 23(2), 141161.

Ibarrola-García, S., \& Iriarte, C. (2012). La convivencia escolar en positivo: mediación y reso lución autónoma de conflictos. Madrid: Pirámide.

Jameson, J.K., Bodtker, A.M., \& Jordan, W.J. (2009). Exploring the role of emotion in con flict transformation. Conflict Resolution Quartley, 27(2), 167-192. doi: $10.1002 / \mathrm{crq} .254$

Jameson, J.K., Bodtker, A., and Linker, T. (2010). Facilitating conflict transformation: media tor strategies for eliciting emotional communication in a workplace conflict. Nego tiaing Journal, 26(1), 25-48. doi: 10.1111/j.1571-9979.2009.00252.x

Jameson, J.K., Sohan, D., and Hodge, J. (2014). Turning points and conflict transformation in mediation. Negotiation Journal, 30(2), 209-229. doi: 10.1111/nejo.12056

Jiang, J.Y., Zhan, X. \& Tjosvold, D. (2013). Emotion regulation as a boundary condition of the relationship between team conflict and performance, multicultural examination. Journal of Organizational Behavior, 34, 714-734. doi:10.1002/job.1834

Jones, T., \& Bodtker, A. (2001). Mediating with heart in mind: addressing emotion in medi ation practice. Negotiation Journal, 17(2), 207-244. doi: 10.1111/j.15719979.2001.tb00238.x

Jones, T.S. (2006). Emotion in mediation: implications, applications, opportunities and chal lenges. En M.S. Herrman, The Blackwell handbook of mediation: bridging theory, research and practice (pp.227-305). USA: Blackwell publishing, Ltd.

Kuder, G. F., \& Richardson, M. W. (1937). The theory of estimation of test reliabil ity.Psychometrika, 2, 151-160.

Ladd, P. (2005). Mediation, conciliation and emotions: a practitioner's guide for understand ing emotions in dispute resolution. USA: University Press of America.

Lane-Garon, P., \& Richardson, T. (2003). Mediator mentors: improving school climate, nur turing student disposition. Conflict Resolution Quartley, 21(1), 47-67. doi: $10.1002 /$ crq.48

Lane-Garon, P., Ybarra-Merlo, M., Zajac, J., \& Viera, T. (2007). Mediators and mentors: partners in conflict resolution and peace education. Journal of Peace Education, 2(2), 183-193.

Lieberman, A. (2006). "A" List of Emotions in mediation from anxiety to agreement. The Dispute Resolution Journal, 61(1), 46-50. 
Long, J., Fabricius, W., Musheno, M., \& Palumbo, D. (1998). Exploring the cognitive and affective capacities of child mediators in a "successful" inner-city peer mediation pro gram. Mediation Quartley, 15(4), 289-302. doi: 10.1002/crq.3890150405

Lund, M. E. (2000). A Focus in Emotion in Mediation Training. Family and Conciliation Courts Review, 38(1), 62-68. doi: 10.1111/j.174-1617.2000.tb00558.x

Maiese, M. (2006). Engaging the Emotions in Conflict Intervention. Conflict Resolution Quarterly, 24(2), 187-96. doi: 10.1002/crq.167

Maoz, I. (2011). Does contact work in protracted asymmetrical conflict? Appraising 20 years and four major models of reconciliation-aimed planned encounters between Israeli Jews and Palestinians. Journal of Peace Research, 48(1), 115-125. doi:10.1177/0022343310389506

Mayer, J. D., Salovey, P., \& Caruso, D. R. (2009). Test de inteligencia emocional MayerSalovey-Caruso (MSCEIT).Madrid: TEA.

Melchin, K., \& Picard, C. (2008). Transforming Conflict through Insight. Toronto: University of Toronto Press.

Minkle, B., Bashir, A., \& Sutulov, C. (2008). Peer consultation for mediators: the use of a holding environment to support mediator reflection, inquiry and self-knowing. Negoti ation Journal, 24(3), 303-323. doi: 10.1111/j.1571-9979.2008.00186.x

Munné, M., \& Mac-Cragh, P. (2006). Los diez principios de la cultura de mediación. Barce lona: Graó.

Murphy, B.C., \& Eisenberg, N. (2002). An integrative examination of peer conflict: chil dren's reported goals, emotions and behaviours. Social Development, 11(4), 534-557. doi: 10.1111/1467-9507.00214

Murciano, D., \& Notó, C. (2005). Mediación escolar. En AA.VV., La mediación esco-lar: una estrategia para abordar el conflicto (pp.25-34). Barcelona: Graó.

Ortega, R., \& Del Rey, R. (2004). Construir la convivencia. Barcelona: Edebé.

Ortega-Ruiz, R., Del Rey, R., \& Casas, J. A. (2016). La Convivencia Escolar: clave en la pre dicción del Bullying. Revista Iberoamericana de Evaluación Educativa, 6(2), 91-102

Paluck, E. L. (2009). Reducing intergroup prejudice and conflict using the media: A field ex periment in Rwanda. Journal of Personality and Social Psychology, 96(3), 574-587. http://dx.doi.org/10.1037/a0011989

Picard, C., \& Melchin, K. (2007). Insight Mediation: A Learning-Centered Mediation Mod el. Negotiation Journal, 23(1), 35-53. doi: 10.1111/j.1571-9979.2007.00126.x 
Picard, C., and Siltaten, J. (2013). Exploring the Significance of Emotion for Mediation Prac tice. Conflict Resolution Quarterly, 31(1), 31-55. doi: 10.1002/crq.21078

Poitras, J. (2007). The paradox of accepting one's share of responsibility in mediation. Nego tiation Journal, 23(3), 267-282. doi: 10.1111/j.1571-9979.2007.00143.x

Redorta, L., Obiols, M., y Bisquerra, R. (2006). Emoción y conflicto: aprenda a manejar las emociones. Barcelona: Paidós.

Rozemblum de Horowitz, S. (2007). Mediación: convivencia y resolución de conflictos en la comunidad. Barcelona: Graó.

Sabucedo, J. M., Durán, M., Alzate, M., and Rodríguez, M. S. (2011). Emotional responses and attitudes to the peace talks with ETA. Revista Latinoamericana de Psicología, 43, 289-296 [http://www.scielo.org.co/pdf/rlps/v43n2/v43n2a08.pdf]

Salovey, P. (1997). Emocional development and emocional intelligence: educational implica tions. New York: Basic Books.

Sargent, N., Picard, C., and Jull, M. (2011). Rethinking Conflict: Perspectives from the In sight Approach. Negotiation Journal, 27(3), 343-66. doi: 10.1111/j.15719979.2011.00311.x

Selfridge, J. (2004). The Resolving Conflict Creatively Program: How we Know it Works. Theory Into Practice, 43(1), 57-67 [http://www.jstor.org/stable/3701565]

Shapiro, D. (2002). Negotiating Emotions. Conflict Resolution Quarterly, 20(1), 67-82. doi: $10.1002 / \mathrm{crq} .11$

Shapiro, D. (2004). Conflict and communication: a guide through the labyrinth of conflict management. New York: International Debate Education Association.

Shapiro, D. (2006). Preempting disaster: pre-mediation strategies to deal with strong emo tions. En M.S. Herrman (Ed.), The Blackwell Handbook of mediation (pp. 309-325). USA: Blackwell Publishing, Ltd.

Shreier, L. (2002). Emotional intelligence and mediation training. Conflict Resolution Quartley, 20(1), 99-119. doi: 10.1002/crq.13

Smilovitz, J. (2008). Emotions and mediations: disputant perception of the mediator. Clingendael Discussion Paper in Diplomacy, 1110, 1-42. [http:// www.clingendael.nl/search/results.html]

Tam, T., Hewstone, M., Cairns, E., Tausch, N., Maio, G., \& Kenworthy, J. (2007). The im pact of intergroup emotions on forgiveness in Northern Ireland. Group Processes y Intergroup Relations, 10, 119-135. doi:10.1177/1368430207071345 
Villaoslada, E., \& Palmeiro, C. (2006). En J.C. Torrego (Coord.), Modelo integrado de mejo ra de la convivencia: estrategias de mediación y tratamiento de conflictos (pp. 69108). Barcelona: Graó.

White, C. and Agne, R. (2009). Communication Practices of Coaches during Mediator Train ing: Addressing Issues of Knowledge and Enactment. Conflict Resolution Quarterly, 27 (1), 83-105. doi: 10.1002/crq.249 


\section{Page intentionally blank}

